\title{
Intervention Effects in Using an Application Compared with a Module with Pictures on Knowledge, Attitude, and Practice of the Pregnant Women in North Sumatra, Indonesia
}

\author{
Herna Rinayanti Manurung ${ }^{1 *}$ (D) Heru Santoso $^{2}$ (D) Kintoko Rochadi $^{3}$ (D), Juanita Juanita ${ }^{4}(\mathbb{D}$ \\ ${ }^{1}$ Public Health Doctoral Program, Faculty of Public Health, Universitas Sumatera Utara, Medan, Indonesia; ${ }^{2}$ Department \\ of Biostatistics, Faculty of Public Health, Universitas Sumatera Utara, Medan, Indonesia; ${ }^{3}$ Department of Health Education \\ and Behavioral Sciences, Faculty of Public Health, Universitas Sumatera Utara, Medan, Indonesia; ${ }^{4}$ Department of Health \\ Administration and Policy Studies, Faculty of Public Health, Universitas Sumatera Utara, Medan, Indonesia
}

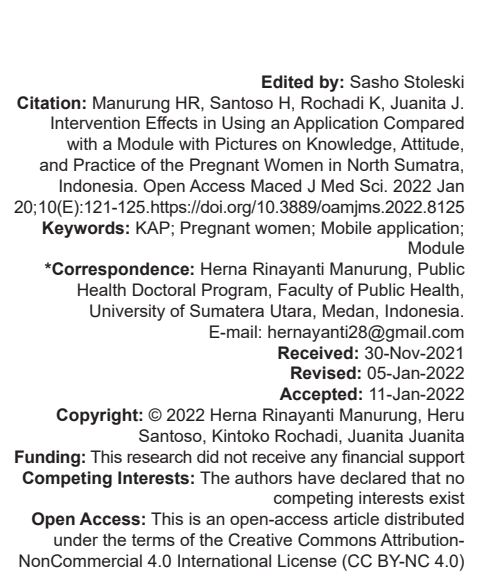

\section{Abstract}

BACKGROUND: Pregnancy period is a crucial period for the maternal and infant health. Unfortunately, there are still many pregnant women having low knowledge, attitude, and practice (KAP). Meanwhile, the advanced technology and the occurrence of pandemic should have created change toward the method to provide education.

AIM: This research aims to compare the KAP of the pregnant women provided by an application with those provided with a module with pictures.

METHODS: This research was conducted in Deli Serdang Regency, North Sumatera Province. There were two groups of pregnant women, each of which consists of 32 people chosen from the pregnant women registered in two Public Health Centers. One group used the application and the other used the module with pictures. After 3 months the KAP of those two groups was measured in accordance with the content of the module.

RESULTS: Those two groups had the profile of the same age and education, but their occupation was different, where the application users were mostly housewives, while the most of the module users were self-employed. The pregnant women using the application had a higher KAP than the pregnant women using the module with pictures.

CONCLUSION: The use of the application and the module with pictures is an important alternative to increase the KAP of the pregnant women.

\section{Background}

The maternal and infant health is reflected from the health indicator of these two groups. Therefore, there are two important indicators, namely, the neonatal mortality and maternal mortality. In Indonesia, based on the 2017 SDKI report [1], there was a decrease of the neonatal mortality rate from 20/1,000 live births in 2002 to become 15/1,000 live births in 2017. However, the rate was still quite far from the 2024 target, where the neonatal mortality rate will be expected to decrease to become $10 / 1,000$ live births. It is also known that the most causes of neonatal mortality are the intrapartum complications $(28.3 \%)$, respiratory and cardiovascular disorder $(21.3 \%)$, low birth weight babies and premature babies (19\%), congenital anomaly (14.8\%), and infection (7.3\%).

Meanwhile, the maternal mortality in Indonesia still becomes a big issue [2], and it is even considered as a major project by the Ministry of Health of the Republic of Indonesia [3] because the rate is still 305/100,000 live births, the highest number in ASEAN. Based on the same report, the direct causes of the maternal mortality are hypertension disorder in pregnancy $(33.1 \%)$, obstetric hemorrhage $(27.03 \%)$, non-obstetric complications $(15.7 \%)$, other obstetric complications $(12.04 \%)$, infection related to pregnancy $(6.06 \%)$, and other causes $(4.81 \%)$.

Both of those reflect other mother and child health $(\mathrm{MCH})$ issues, which are still big problems in Indonesia, which among others are stunting, diseases in infants, and the growth problem of infants. Actually, these problems in pregnant women and infants can really be dealt with, starting from the pregnancy period, while the women are still pregnant. Increasing the quality of ANC means having double strengths for the pregnant women and their baby [1].

Education on the importance of pregnancy and the needs of the pregnant women is crucial because many pregnant women do not even have good knowledge, attitude, and practice (KAP) [4], [5], [6], and that includes the pregnant women in Indonesia [7]. Unfortunately, the Ministry of Health of Indonesia has had applied only the conventional method, which is giving an ANC book to pregnant women without introducing the book and 
without interesting appearance of the book. Meanwhile, the development of the era and technology demands the health sector to adapt and adjust when education is carried out [8], [9]. At present, technology has developed so rapidly that every mother in an urban area has a mobile phone and has been exposed to various shows on TV which make them have ideal figures that directly and indirectly influence their imagination [10], [11]. Moreover, in this pandemic era, the education service for pregnant women should be carried out still, without any socio-economic or location limitation because we still do not know when this pandemic will be over [12], [13].

This research attempts to design and test two methods at once, namely, providing information on pregnancy in a form of an application compared with a module with pictures. The effectivity of those two methods in increasing the KAP of the pregnant women, particularly in their third trimester of pregnancy, will be tested.

\section{Methods}

This study applies a quasi-experimental method [14]. The research location is Deli Serdang Regency, North Sumatera Province. The respondents were the pregnant women in their third trimester of pregnancy and they were divided into two groups. There are 32 pregnant women receiving the application and the other 32 pregnant women receiving the module with pictures. These pregnant mothers were the group of pregnant women having been monitored by the health workers since their first trimester of pregnancy.

\section{The application and module}

The application is designed to be able to be downloaded using the Android-based mobile phone. Because it was still in the testing phase, the application was still in a form of a dummy so that it had the potential to be improved in the future. The application contains modules that can be learned independently by the respondents and contains some personal information of the respondents. Besides being advantageous to become a module, the application can be used to interact with the health worker through SMS or a phone call. To be able to use the application, every pregnant woman has to type down their name and phone number. The application control was done by the admin staff working in the Public Health Center.

The module with pictures is made interesting and easy to read, using the movie figures who are popular. The content is made using the references from the guidance for pregnant women issued by the Ministry of Health of Indonesia and from other sources. There are 34 pages in the module with pictures that can be learned independently by the pregnant women.

\section{KAP}

After the dissemination of information was done for around 3 months, at the end of their third trimester of pregnancy for every participant, KAP evaluation was conducted. The content of this KAP is a questionnaire with ten knowledge questions, five attitude questions and five practice questions.

The questions on knowledge and practice are made in a form of three answer choices, namely, "yes," "no," and "do not know." Meanwhile, the answer of the attitude questions is designed using a Likert scale 1-5 with positive answers. To calculate the total scores of the respondent, the answer "yes" is given 2 scores, the answer "no" is given 0 , and the answer "do not know" is given 1 score (the knowledge and practice category). Meanwhile, for attitude, every answer is given scores 1 , $2,3,4$, or 5 each. To discover the differences of KAP, the statistic test with the independent t-test sample was conducted at the testing level of $\alpha=0.05$.

\section{Research ethics}

The permit of research ethics was issued by the Ethics Committee of the Faculty of Medicine of Universitas Sumatera Utara. While the information dissemination was conducted, the participants were asked to fill in the informed consent that had to be signed, and it contains information on their rights to withdraw from the research anytime when they wished to do so.

\section{Results}

Both groups of the pregnant women receiving the application and receiving the module were dominated by the $21-35$ aged group, $56.2 \%$ and $75 \%$, respectively (Table 1). The education of both groups was also dominated by the Senior High School education, which is $62.5 \%$ for the group receiving the application and $56.2 \%$ for the group receiving the module. The

Table 1: Comparison of the demographic profile of the application group and module group

\begin{tabular}{|c|c|c|c|c|}
\hline \multirow[t]{2}{*}{ Characteristic } & \multicolumn{2}{|c|}{$\begin{array}{l}\text { Application's } \\
\text { participants }(\mathrm{n}=32)\end{array}$} & \multicolumn{2}{|c|}{$\begin{array}{l}\text { Module's } \\
\text { participants }(n=32)\end{array}$} \\
\hline & $f$ & $\%$ & $f$ & $\%$ \\
\hline \multicolumn{5}{|l|}{ Age } \\
\hline$\leq 20$ years old & 8 & 25 & 1 & 3.1 \\
\hline $21-35$ years old & 18 & 56.2 & 24 & 75 \\
\hline$>35$ years old & 6 & 18.8 & 7 & 21.9 \\
\hline \multicolumn{5}{|l|}{ Education } \\
\hline $\begin{array}{l}\text { Elementary school to junior high } \\
\text { school }\end{array}$ & 3 & 9.4 & 5 & 15.6 \\
\hline Senior high school & 20 & 62.5 & 18 & 56.2 \\
\hline Diploma and undergraduate & 9 & 28.1 & 9 & 28.2 \\
\hline \multicolumn{5}{|l|}{ Occupation } \\
\hline Housewife & 14 & 43.8 & 4 & 12.5 \\
\hline Self-employed & 5 & 15.7 & 12 & 37.4 \\
\hline Private company employee & 7 & 21.8 & 9 & 28.2 \\
\hline Civil Servant & 2 & 6.2 & 2 & 6.2 \\
\hline Local trader & 4 & 12.5 & 5 & 15.7 \\
\hline
\end{tabular}


occupation of the group receiving the application is mostly housewives, whereas the group receiving the module is dominated by self-employed women.

The application contains modules that can be learned by the pregnant women. The modules are divided into four categories, namely, about pregnancy, pregnancy examination, the health of pregnant women, and tips to maintain the health of pregnant women. Every module has subcategories that can be selected as pointed in Figure 1.

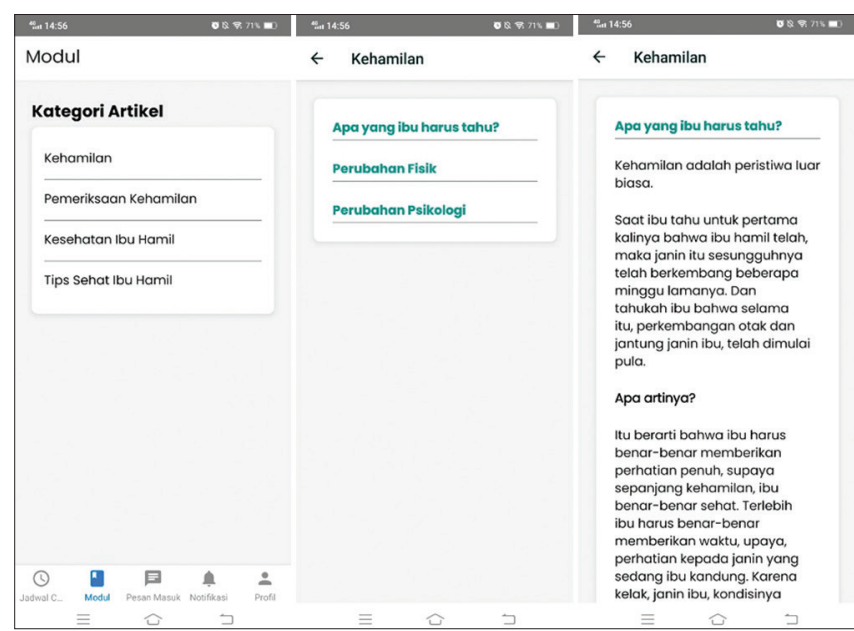

Figure 1: The application containing the modules that can be learned by the pregnant women

Meanwhile, the module with pictures was given to the other group. The content of the module with pictures is important matters that pregnant mothers must know and that are related to the pregnancy examination, as also found in the application but in a form of pictures (Figure 2).

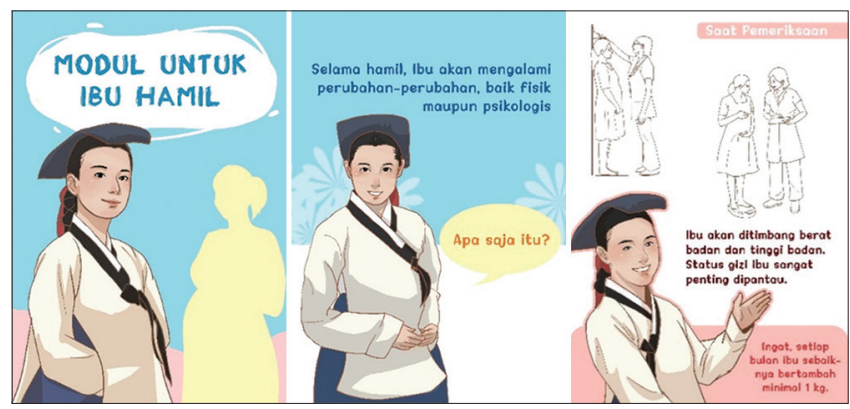

Figure 2: The module's cover and several pictures in the module

After the information dissemination of the application and the module was conducted, the differences of KAP between the application receivers and the module receivers could be noticed (Figure 3 ). For the overall KAP, the application receivers have the scores a lot higher than the scores of the module receivers. The differences lie in the range of 2.10 for knowledge, 1.44 for attitude, and 2.04 for practice. When the statistic test was conducted, there was a significant difference $(p<0.05)$ as shown in Table 2.

Table 2: Statistic test results

\begin{tabular}{llll}
\hline Category & Respondent & Mean difference $(\mathrm{Cl})$ & p-value \\
\hline Knowledge & $\begin{array}{l}\text { Application Receivers } \\
\text { Module Receivers }\end{array}$ & $2.10(1.36-2.85)$ & 0.000 \\
Attitude & $\begin{array}{l}\text { Application Receivers } \\
\text { Module Receivers }\end{array}$ & $1.44(0.52-2.35)$ & 0.003 \\
Practice & $\begin{array}{l}\text { Application Receivers } \\
\text { Module Receivers }\end{array}$ & $2.04(0.99-3.09)$ & 0.000 \\
\hline
\end{tabular}

\section{Discussion}

Health education addressed to pregnant women in Indonesia mostly still uses the face-to-face meeting method, pamphlets, audiovisual training, and mass media campaign. However, at this time, the online technology development in increasing the maternal health has gained recognition. In the $71^{\text {st }}$ World Health Assembly in 2018, all the $\mathrm{WHO}$ delegations agreed on the resolution on digital health. The member states encouraged the development and the increase of the use of digital technology in health to become the priority to accomplish the Universal Health Coverage and other SDGs purposes [15].

Technology development in the maternal and infant health has indeed expanded. One of the results is the use of the mobile phone-based application. In Senegal, the mobile health intervention ( $\mathrm{m}$-Health) is applied to increase the maternal health service in the rural and remote areas [10]. The application named "matrones" provides education on resting and appropriate nutrition during pregnancy and is designed to ask questions on the signs and symptoms of danger that might need to be referred to a health post, such as having swollen hands and feet or gynecologic hemorrhage.

The effectivity of technology use, particularly the one with a mobile device for pregnant women, gives a very significant influence [16]. First, the application use can encourage the mothers to breastfeed their babies more often. Second, for health service use, the application can increase the frequency of ANC visitations. Third, with the application, delivery process assistance by a health worker can improve. When compared with the use of the conventional methods, like using pamphlets, the technology-based application can reduce the maternal and new born baby's health problems because the information contained in the application or the communication method is more visual. The review conducted showed that if the application provides notification/reminder for the users, the tendency to follow the schedule of treatment/ service will be higher than if there is no notification at all [17]. Qualitatively, the effectivity of CommCare has improved the condition of the pregnant women and also their health during their reproduction period in general [10].

This research shows a significant difference statistically (Table 2) toward KAP of the application users, compared with the respondents only given the module with pictures (Figure 2). Despite being different, those two models are still quite effective, compared with the use of a conventional book only. The increase of KAP will create empowerment to pregnant women so that they are capable of improving their health and pregnancy quality since early on [18], [19], [20]. On the contrary, the low KAP scores will become the risk factor that will produce 


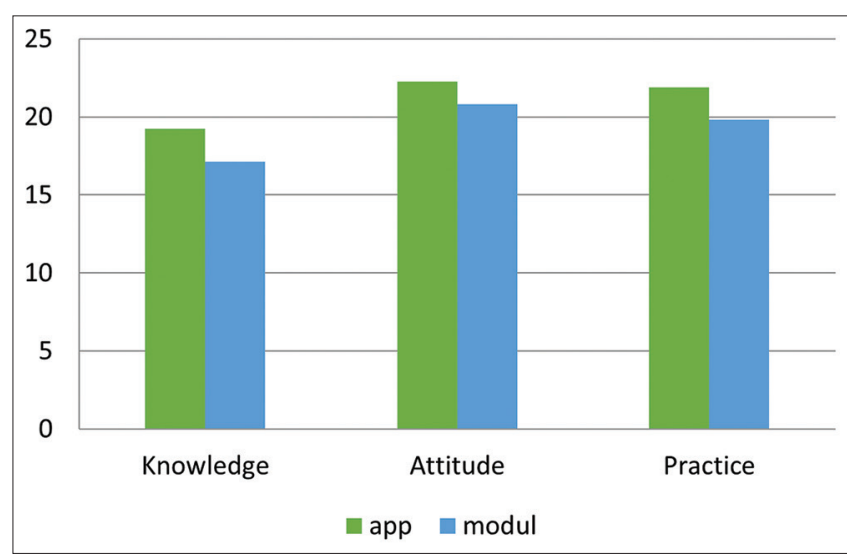

Figure 3: The differences of knowledge, attitude, and practice (KAP) of the app users compared with the KAP of the users of the module with pictures

illnesses and death for the mothers and their babies in the future [21], [22], [23].

In many countries, most women visit the ANC service to acquire knowledge and information on pregnancy and the delivery process [24]. In the situation where there are service limitations, occasionally, the use of pictures and stories of any kind can revive the feeling of empowerment and has positive impact in the behavior change of someone targeted to be changed [25], [26], [27]. In other words, the service of pregnant women without correct explanation or with the not up-to-date and irrelevant information will become barriers and limit the access of the pregnant women in the future. Thus, with the use of the module with pictures such as done in this research, it is an option whose advantages cannot be denied to replace the conventional module. The visual description in a form of pictures provides a mirror producing empathy [28], [29], [30] on how the pregnant mothers are supposed to behave.

As discovered by the previous studies [31], [32], [33], [34], this research also shows the fact having very strong grounds. The fact is that the KAP of pregnant women has to be really intervened since the pregnancy period, using the directed and focused efforts if we would like to see positive outcomes from the $\mathrm{MCH}$ condition.

\section{Conclusion}

The use of the application and the module with pictures is one of the alternatives to increase the KAP of pregnant women. The intervention to increase KAP will be very beneficial if conducted at least in the pregnancy period. Although conducted at the same time, the application was proven to have higher KAP scores than the module with pictures.

\section{References}

1. Ministry of Health. Statistics Indonesia NP, FP Board, Ministry of Health, and ICF International, Indonesia Demographic and Health Survey 2012. Jakarta: BPS, BKKBN, Kemenkes, and ICF International; 2013.

2. Zaluchu F. Gender Inequality, Behind Maternal Mortality in Nias Island, North Sumatra, Indonesia. Amsterdam: University of Amsterdam; 2018.

3. Renstra Kemenkes. Kemenkes, Peraturan Menteri Kesehatan RI No. 21 Tahun 2020 Tentang Renstra Kemenkes Tahun 2020$2024 ; 2020$.

4. Devkota R, Khan GM, Alam K, Sapkota B, Devkota D. Impacts of counseling on knowledge, attitude and practice of medication use during pregnancy. BMC Pregnancy Childbirth. 2017;17:131. https://doi.org/10.1186/s12884-017-1316-6

5. Habeeb A, Dala H, Alani A, Abdul B, Hassan R, Mohd A. Osong public health and research perspectives use, awareness, knowledge and beliefs of medication during pregnancy in Malaysia. Osong Public Health Res Perspect. 2020;11(6):3739. https://doi.org/10.24171/j.phrp.2020.11.6.05 PMid:33403200

6. Tefera YG, Gebresillassie BM, Mersha AG. Beliefs and risk awareness on medications among pregnant women attending the antenatal care unit in Ethiopia university hospital overestimating the risks is another dread. Front Public Health. 2020;8:28. https://doi.org/10.3389/fpubh.2020.00028 PMid:32195214

7. Wijaya-Erhardt M, Muslimatun S, Erhardt JG. Effect of an educational intervention related to health and nutrition on pregnant women in the villages of Central Java Province, Indonesia. Health Educ J. 2014;73(4):370-81. https://doi. org/10.1177\%2F0017896913485741

8. Bolin RC. Mobile Health Technology and Health Behavior A Look into the Workplace Setting. University of Kentucky; 2013.

9. Kreps GL, Neuhauser L. New directions in eHealth communication Opportunities and challenges. Patient Educ Couns. 2010;78(3):329-36. https://doi.org/10.1016/j.pec.2010.01.013 PMid:20202779

10. Macdonald ME, Diallo GS. Socio-cultural contextual factors that contribute to the uptake of a mobile health intervention to enhance maternal health care in rural Senegal. Reprod Health. 2019;16(1):141. https://doi.org/10.1186/s12978-019-0800-z PMid:31511028

11. Sutherland T, Choi D, Yu C. Brought to life through imagery animated graphic novels to promote empathic, patient-centred care in postgraduate medical learners. BMC Med Educ. 2021;21(1):66. https://doi.org/10.1186/s12909-021-02491-4 PMid:33478483

12. Eyanoer PC, Zaluchu F. COVID-19 and the fourth burden of women in developing countries: A mini review. Open Access Maced J Med Sci. 2020;8:476-9. https://doi.org/10.3889/oamjms.2020.5470

13. Sarumpaet S, Zaluchu F, Eyanoer PC, Simanjuntak NH. Fighting against COVID-19 and fighting against stigma. Open Access Maced J Med Sci. 2020;8(T1):522-5.

14. Zaluchu F. Metodologi Penelitian Kesehatan. Bandung: Cipta Pustaka Media; 2006.

15. PAHO. $71^{\text {st }}$ World Health Assembly Wraps up with Adoption of Resolutions on Wide-Ranging Topics; 2018. Available from: https://www3.paho.org/hq/index.php?option=com con tent\&view=article\&id=14391:71 st-world-health-assemblywraps-up-with-adoption-of-resolutions-on-wide-rangingtopics\&ltemid=1926\&lang=en [Last accessed 2021 Oct 16]. 
16. Palmer MJ, Henschke N, Bergman H, Villanueva G, Maayan N, Tamrat $\mathrm{T}$, et al. Targeted client communication via mobile devices for improving maternal, neonatal, and child health. Cochrane Database Syst Rev. 2020;8:CD013679. https://doi. org/10.1002/14651858.CD013679 PMid:32813276

17. Ciapponi A, Lewin S, Herrera CA, Opiyo N, Pantoja T, Paulsen $\mathrm{E}$, et al. Delivery arrangements for health systems in low-income countries: An overview of systematic reviews. Cochrane Database Syst Rev. 2017;9(9):CD011083. https://doi. org/10.1002/14651858.CD011083 PMid:28901005

18. Bianchi CM, Huneau J, Le Goff G, Verger EO, Mariotti F, Gurviez P. Concerns, attitudes, beliefs and information seeking practices with respect to nutrition-related issues: A qualitative study in French pregnant women. BMC Pregnancy Childbirth. 2016;16(1):306. https://doi.org/10.1186/s12884-016-1078-6 PMid:27729021

19. Kim SS, Nguyen PH, Yohannes $\mathrm{Y}$, Abebe $\mathrm{Y}$, Tharaney M, Drummond $\mathrm{E}$, et al. Behavior change interventions delivered through interpersonal communication, agricultural activities, community mobilization, and mass media increase complementary feeding practices and reduce child stunting in Ethiopia. J Nutr. 2019;149(8):1470-81. https://doi.org/10.1093/jn/nxz087 PMid:31165869

20. Kim SS, Rawat R, Mwangi EM, Tesfaye R, Abebe Y, Baker J, et al. Exposure to large-scale social and behavior change communication interventions is associated with improvements in infant and young child feeding practices in Ethiopia. PLoS One. 2016;11(10):e0164800. https://doi.org/10.1371/journal. pone. 0164800 PMid:27755586

21. Agus $\mathrm{Y}$, Horiuchi S, Porter SE. Rural Indonesia women's traditional beliefs about antenatal care. BMC Res Notes. 2012;5(1):589. https://doi.org/10.1186/1756-0500-5-589 PMid:23106915

22. Agus $\mathrm{Y}$, Horiuchi $\mathrm{S}$. Factors influencing the use of antenatal care in rural West Sumatra, Indonesia. BMC Pediatr. 2012;12:9. https://doi.org/1471-2393/12/9 PMid:22353252

23. Wulandari LP, Whelan AK. Beliefs, attitudes and behaviours of pregnant women in Bali. Midwifery. 2011;27(6):867-71. https:// doi.org/10.1016/j.midw.2010.09.005

PMid:21131110

24. Downe S, Finlayson K, Tunçalp O, Am G. Provision and uptake of routine antenatal services: A qualitative evidence synthesis. Cochrane Database Syst Rev Provis. 2019;6:CD012392. https://doi.org/10.1002/14651858.CD012392.pub2 PMid:31194903
25. Shimazaki T, Matsushita M, lio M, Takenaka K. Use of health promotion manga to encourage physical activity and healthy eating in Japanese patients with metabolic syndrome: A case study. Arch Public Health. 2018;76:26. https://doi.org/10.1186/ s13690-018-0273-5

26. Kilanowski JF. Agricultural safety comic book for latinx migrant families: Development and evaluation. J Pediatr Health Care. 2020;34(3):230-8. https://doi.org/10.1016/j.pedhc.2019.11.003 PMid:31983514

27. Cedri S, Briguglio E, Cedri C, Masellis A, Crenca A, Pitidis A, et al. Development of an effective communication strategy for the prevention of burns in children: The PRIUS project. Ann Burns Fire Disasters. 2015;28(2):88-93 PMid:27252606

28. King AJ. Using comics to communicate about health: An introduction to the symposium on visual narratives and graphic medicine. Health Commun. 2017;32(5):523-4. https://doi.org/10 $.1080 / 10410236.2016 .1211063$

29. Alemany-Pagès $M$, Azul AM, Ramalho-Santos J. The use of comics to promote health awareness: A template using nonalcoholic fatty liver disease. Eur J Clin Invest. 2021;2021:13642. https://doi.org/10.1111/eci.13642

30. Whiting J. Comics as reflection: In opposition to formulaic recipes for reflective processes. Perm J. 2020;19:134. https:// doi.org/10.7812/TPP/19.134

31. Kamau M, Mirie W, Kimani S, Mugoya I. Effect of community based health education on knowledge and attitude towards iron and folic acid supplementation among pregnant women in Kiambu County, Kenya: A quasi experimental study. PLoS One. 2019;14(11):e0224361. https://doi.org/10.1371/journal.pone.0224361 PMid:31765422

32. Nair N, Tripathy P, Costello A, Prost A. Mobilizing women's groups for improved maternal and newborn health: Evidence for impact, and challenges for sustainability and scale up. Int J Gynaecol Obstet. 2012;119(Suppl):S22-5. https://doi. org/10.1016/j.ijgo.2012.03.014 PMid:22883914

33. Prost A, Colbourn T, Seward N, Azad K, Coomarasamy A, Copas A, et al. Women's groups practising participatory learning and action to improve maternal and newborn health in low-resource settings: A systematic review and meta-analysis. Lancet. 2013;381(9879):1736-46. https://doi.org/10.1016/ S0140-6736(13)60685-6 PMid:23683640

34. Sado L, Spaho A, Hotchkiss DR. The influence of women's empowerment on maternal health care utilization: Evidence from Albania. Soc Sci Med. 2014;114:169-77. https://doi. org/10.1016/j.socscimed.2014.05.047

PMid:24929918 